\title{
Indomethacin as a
} postoperative analgesic for total hip arthroplasty

R. Segstro BSc MD, P.K. Morley-Forster MD FRCPC, G. Lu

This prospective, randomized, double-blind trial evaluated the efficacy of rectal indomethacin as an adjunct to morphine for controlling postoperative pain. Fifty healthy patients undergoing elective hip arthroplasty were investigated. Group $/(n=$ $25)$ received placebo suppositories, Group $2(n=25)$ received indomethacin suppositories, $100 \mathrm{mg} q 8 \mathrm{hr}$ for five doses, starting at the end of the procedure. Both groups received morphine via a PCA pump, which recorded the amount of morphine delivered each hour. After a standardized general anaesthetic, PCA was begun in the recovery room. Pain was measured with a standard $100 \mathrm{~mm}$ VAS at 2, 6, 20,28, $42 \mathrm{hr}$ after surgery and the morphine consumption recorded. Over the 42-hr study period, patients in Group 2 required less morphine than those in Group 1 (34.8 $\pm 21.8 \mathrm{mg}$ vs $89.6 \pm 43.7, P<0.01)$. Pain scores were lower in Group 2 at 20, 28, $42 \mathrm{hr}$ postoperatively. The incidence of side-effects did not differ between groups and no patient had excessive postoperative bleeding. The combination of indomethacin and morphine provided superior pain relief to morphine alone even though the control group had liberal access to morphine. This synergistic effect would make indomethacin a useful adjunct to intramuscular or epidural narcotics.

Cette étude prospective randomisée et à double insu a évalué l' efficacité de l' indométhacine par voie rectale comme adjuvant a la morphine pour contrôler la douleur postopératoire. Cinquante patients en bonne santé devant subir une arthroplastie de la hanche élective furent investigués. Le Groupe $I(n=25)$ a reçu des suppositoires de placebo. le Groupe $(n=25)$ a reçu des suppositoires d' indométhacine, $100 \mathrm{mg}$ q8hre pour cinq doses débutant à la fin de la procédure. Les deux groupes ont reçu de

\section{Key words}

ANALGESIA: PCA; postoperative;

ANALGESICS: indomethacin, morphine;

PAIN: postoperative;

SURGERY: orthopaedic.

From the Department of Anacsthesia, St. Joseph's Health Centre, University of Western Ontario, London, Ontario, Canada.

Address correspondence to: Dr. P. Morlcy-Forster, Department of Anaesthesia, St. Joseph's Health Centre, 268 Grosvenor St., London, Ontario.

Accepted for publication I8th February, 1991. la morphine à travers une pompe PCA qui a enregistré la quantité de morphine délivrée à chaque heure. Après standardisation de l'anesthésie générale, le PCA fut commencé en salle de réveil. La douleur fut mesurée avec un VAS standard $100 \mathrm{~mm}$ en 2, 6, 20,28, 42 heures après la chirurgie et la consommation générale de morphine fut enregistrée. Pour une période d'étude de 42 heures, les patients du Groupe 2 ont requis moins de morphine que ceux du Groupe I (34,8 $\pm 21,8 \mathrm{mg}$ vs 89,6 \pm 43.7, $P<0,011$ ). Les échelles de douleur étaient plus basses dans le Groupe 2 avant 20,28, 42 heures après la chirurgie. $L$ 'incidence des effets secondaires $n$ 'était pas différente entre les deux groupes et aucun patient n'a démontré de saignement postopératoire excessif. La combinaison de l'indométhacine et de la morphine a fourni un soulagement de la douleur supérieur à la morphine seule même si le groupe contrôle avait accès d'une manière libérale à la morphine. Les effets sénergétiques pourraient rendre à l'indométhacine une addition utile aux narcoriques intramusculaires ou une injection épidurale.

Pain after total hip arthroplasty can be difficult to control. The quality of analgesia may influence the patient's early postoperative rehabilitation. ${ }^{1}$ Patient-controlled analgesia (PCA) infusion pumps have greatly improved manghement of postoperative pain for many procedures including joint replacements. However, there are still problems with the technique. Patients may experience narcoticinduced drowsiness, dysphoria, or nausea and will reduce PCA requests to limit these side-effects, which leads to inadequate pain relief. ${ }^{2}$

Indomethacin, a non-steroidal anti-inflammatory drug (NSAID) was originally introduced in 1962 to treat arthritic pain. Intravenous ${ }^{3,4}$ and rectal ${ }^{5,6}$ indomethacin, in combination with narcotics, have been used in Europe for postoperative analgesia after major abdominal and thoracic surgery. Although NSAID's have been increasingly recommended for alleviating chronic pain, ${ }^{7}$ very little has been published in North America on their role in postoperative pain management. We designed a prospective randomized double-blind clinical trial to evaluate the effect of indomethacin on narcotic requirements and pain relief after major orthopaedic reconstructive surgery.

\section{Methods}

Fifty healthy patients, ASA physical status I and II, undergoing elective total hip arthroplasty were studied. 
All patients gave informed consent and the protocol was approved by the institutional ethics committee. Patients were excluded if there was a history of peptic ulcer disease, bleeding tendency, or hypersensitivity to NSAIDS or to morphine.

Patients were assigned to one of two groups according to a randomization schedule prepared by the hospital pharmacy. One group received indomethacin rectal suppositories, $100 \mathrm{mg} \mathrm{q} 8 \mathrm{hr}$ after surgery while the other received placebo suppositories. The first suppository was given in the operating room at the end of the procedure. Patients in both groups received iv morphine via a PCA infusion pump (Bard Harvard PCA). The machine retains a continuous record of the amount of morphine delivered and the number of medication requests.

Intraoperatively, a standardized general anaesthetic protocol was followed with avoidance of narcotic premedication, and limitation of intraoperative fentanyl to less than $7 \mu \mathrm{g} \cdot \mathrm{kg}^{-1}$. No narcotic was given within one hour before the conclusion of surgery.

In the recovery room, analgesia was initiated with iv morphine 2-4 mg, q5-10 min administered at the nurses' discretion. When the patient was sufficiently awake to cooperate, PCA was begun. The pump was programmed to deliver $2 \mathrm{mg}$ injections with a lock-out time of six minutes. These settings were found from previous experience to be suitable for arthroplasty patients.

Each subject was asked to assess his postoperative pain subjectively at $2,6,20,28$ and 42 hr after surgery by standard $100 \mathrm{~mm}$ visual analogue scales. Cumulative morphine consumption including that given in recovery room was recorded and side-effects were elicited by direct questioning.

Morphine requirements between groups at each time interval were analyzed using analysis of variance with repeated measures. Pain scores were compared using the Mann Whitney $U$ test. A $P$-value of $<0.05$ was considered significant. Side-effects were compared with the Chi-square test of proportions using Fisher's exact test where appropriate.

TABLE I Demographic characteristics

\begin{tabular}{lll}
\hline & $\begin{array}{l}\text { Placebo } \\
(n=22)\end{array}$ & $\begin{array}{l}\text { Indomethacin } \\
(n=25)\end{array}$ \\
\hline Males & 11 & 11 \\
Females & 11 & 14 \\
ASA I & 5 & 4 \\
ASA Il & 17 & 21 \\
Osteoarthritis & 20 & 20 \\
Other diagnoses & 2 & 5 \\
$\quad$ Age (yr) & $64.6 \pm 8$ & $66.4 \pm 7.8$ \\
WI (kg) & $79.2 \pm 16.9$ & $73.9 \pm 12.7$ \\
Intraoperative fentanyl $(\mu \mathrm{g})$ & $324 \pm 109$ & $311 \pm 123$ \\
\hline
\end{tabular}

Mean values $\pm S D$.

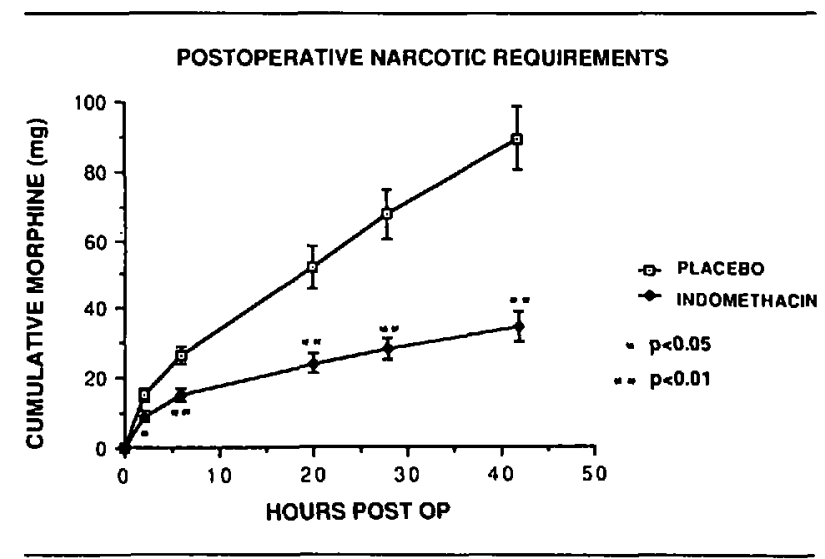

FIGURE I Cumulative morphinc consumption (mg) measured at 2,6. $20,28,42 \mathrm{hr}$ postoperatively. The error bars represent SEM.

\section{Results}

Three patients in the placebo group were withdrawn from the study; in two, the PCA pump's internal record of narcotic administration was lost, and one patient did not receive all the suppositories. This left 22 patients in the placebo group and 25 in the indomethacin group for analysis. The groups did not differ with respect to age, sex, weight, ASA physical status, type of arthritis, or amount of intraoperative fentanyl administered (Table I).

The results of morphine use and pain scores are summarized in Figures 1 and 2. Over the 42-hr study period, patients in the indomethacin group required less morphine than those in the placebo group $(34.8 \pm 21.8$ mg vs $89.6 \pm 43.7, . P<0.01$ ). Morphine requirements in each time interval were lower in the indomethacin than in the placebo group $(P<0.05)$. Pain scores were lower in those treated with indomethacin at 20, 28, and $42 \mathrm{hr}$ postoperatively $(P<0.05)$.

The incidence of side-effects did not differ between the two groups (Table II). Patients tolerated the suppositories well. There were no episodes of GI bleeding and no one experienced excessive postoperative bleeding.

\section{Discussion}

This study demonstrated that using rectal indomethacin as an adjunct to intravenous PCA morphine after total hip arthroplasty resulted in reduced morphine requirements and improved pain scores. The decreased narcotic requirements were observed within the first two hours of surgery. This is consistent with pharmacokinetic studies which demonstrated peak serum indomethacin levels within one hour of rectal administration. Pain scores were less in the indomethacin group after $20 \mathrm{hr}$ postoperatively. This is in agreement with other studies which showed superior pain scores beginning on the first day after surgery. s.6.8 $^{-6}$

Reasbeck et al, assessed the efficacy of rectal indo- 


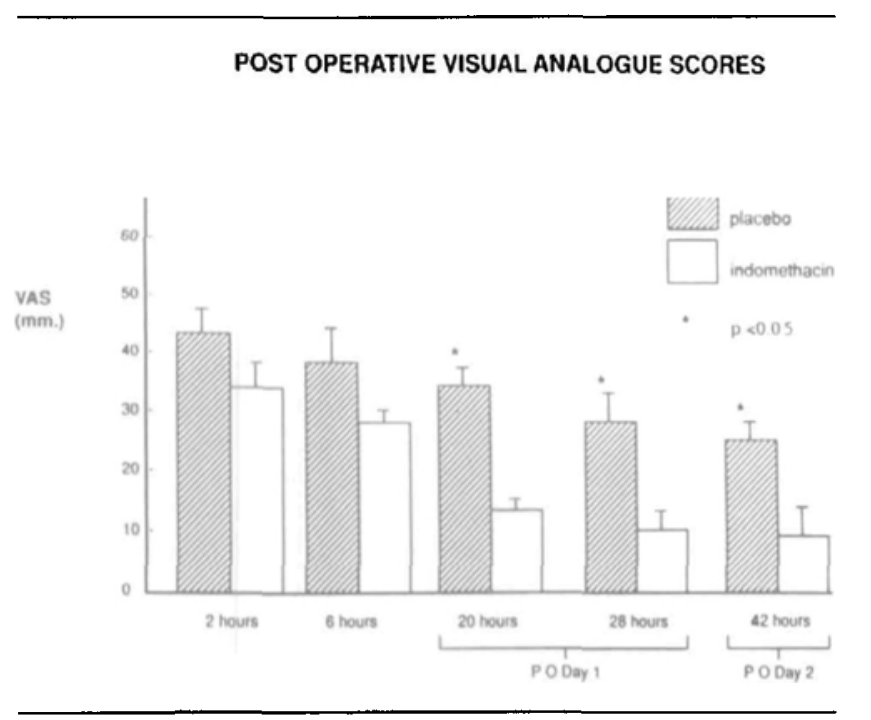

FIGURE 2 Visual analogue scores measured at 2, 6, 20, 28 and $42 \mathrm{hr}$ postoperatively. The enor bars represent SEM.

methacin as an adjunct to narcotics after major abdominal surgery. Indomethacin resulted in decreased narcotic administration and improved subjective pain scores. ${ }^{5}$ This finding was confirmed by Thind and Sigsgaard. ${ }^{6}$ The analgesic effects of rectal indomethacin, cryoanalgesia, and im narcotics for post-thoracotomy pain were compared by Keenan. He found indomethacin to be more effective than cryoanalgesia alone, and when used in conjunction with cryoanalgesia had a synergistic effect on controlling pain on movement. ${ }^{8}$ An indomethacin infusion was found to be an effective adjunct to morphine for postoperative analgesia in children ${ }^{3}$ and after ankle surgery. ${ }^{4}$

The PCA pump proved to be a valuable research tool. Not only did it permit the recording of morphine administration on an hourly basis, but it eliminated possible bias of the nursing staff in judging whether more narcotics were required. It is interesting that despite liberal access to morphine, patients in the placebo group did not achieve equal analgesia. This confirmed our own experience, and that of others that patients will balance the level of analgesia against the side-effects experienced with higher doses. Combining indomethacin with a narcotic seemed to enhance the quality of analgesia. This increased efficacy may be due to the different sites of action of the two analgesics.

The mechanism of action of indomethacin has not been fully elucidated. Arachidonic acid is produced in response to cell membrane damage, and then broken down to produce prostaglandins PGE2 and PGF2 $\alpha$. These mediators induced a state of heightened sensitivity to mechanical or chemical stimuli in the peripheral sensory nerves. Indomethacin inhibits the enzyme cyclo-oxygenase, one of the key enzymes in this arachidonic breakdown cascade,
TABLE II Side effects

\begin{tabular}{lll}
\hline & Placebo & Indomethacin \\
Nausea & $7(5)$ & $14(6)$ \\
Heartburn & 3 & 0 \\
Headache & 2 & 2 \\
Confusion & 0 & 2 \\
Drowsiness & 2 & 2 \\
Itching & 2 & 0 \\
\hline
\end{tabular}

The number of patients nauseated six hours after surgery is shown in parentheses.

thereby blocking the production of prostaglandins. ${ }^{10}$ It is this peripheral site of action, independent of opiate receptors that may account for the enhancement of narcotic analgesia by indomethacin.

It has been shown that the best analgesic dose of an NSAID is not necessarily the same as the anti-rheumatic dose. ${ }^{7}$ Our dose of $100 \mathrm{mg}$ q $8 \mathrm{hr}$ was the same as that used safely in other postoperative pain trials. ${ }^{5,6,8}$ Although higher than the usual daily anti-rheumatic dose, it appears to be well-tolerated for limited periods of time.

Indomethacin use has been associated with headache, dizziness, nausea, diarrhoea, heartburn and gastrointestinal bleeding. Rectal preparations tend to produce a lower incidence of side-effects than oral administration. ${ }^{9}$ In this study, the incidence was generally low and no difference was observed between the two groups. Although the overall incidence of nausea appears high $(45 \%)$, this included post-anaesthetic nausea. Looking only at nausea which persisted beyond six hours postoperatively, the incidence of nausea was $23 \%$ in the placebo group and $24 \%$ in the indomethacin group. Indomethacin did not reduce the incidence of nausea.

The major potential side-effect was GI bleeding. In our relatively small population of 47 patients, we did not encounter this problem. To rule out its occurrence completely we would have had to analyze stool for occult blood. Previous studies of short-term use $(<48 \mathrm{hr})$ of indomethacin for postoperative pain did not note an increased incidence of gastrointestinal bleeding. Keenan reported that in over 4000 mixed surgical cases where rectal indomethacin was used postoperatively, only one case of gastrointestinal haemorrhage occurred. ${ }^{10} \mathrm{We}$ excluded patients with a history of ulcer disease and recommend others do the same.

Increased bleeding from the surgical site is another potential complication. Indomethacin inhibits platelet aggregation in proportion to its serum concentration and can prolong bleeding time. In one postoperative study, iv indomethacin did lengthen bleeding time, but not beyond the normal range. ${ }^{12}$ Taivainen also noted slightly pro- 
longed bleeding times, but did not observe any serious bleeding complications. ${ }^{13}$ In the paediatric population, Maunuksela showed no change in bleeding time with iv indomethacin, but there was a slightly increased incidence of postoperative bleeding. ${ }^{14}$ The other trials ${ }^{3,4.15}$ found no increase in postoperative bleeding.

Patients undergoing joint replacement are at risk for deep venous thrombosis and pulmonary embolus. For prophylaxis, oral warfarin is started the night before surgery. Warfarin does not begin to affect coagulation until 36-72 hr after administration. ${ }^{16}$ Indomethacin has been shown not to affect prothrombin time or plasma warfarin concentration in patients taking warfarin. ${ }^{17}$ Our study was designed so that the final indomethacin suppository was given approximately $48 \mathrm{hr}$ after the initial dose of warfarin. Rectal indomethacin has a relatively short half life of 4-8 $\mathrm{hr}^{18}$ and its effect on platelets lasts only while the serum drug concentration is high. To minimize potential interaction, the final indomethacin suppository should be given no more than $40 \mathrm{hr}$ after the preoperative warfarin dose.

Intravenous infusions of indomethacin produce more consistent serum levels than rectal suppositories. ${ }^{18}$ Since the intravenous form is currently not available in North America, except for use in premature infants, knowledge of the effects of rectal indomethacin are more clinically useful.

The results of our study show that indomethacin suppositories reduce morphine requirements and improve the quality of postoperative analgesia after total hip arthroplasty. Indomethacin may be a useful supplement to im narcotics if a PCA pump is not available. Other potential uses would be as a supplement to epidural narcotics where systemic narcotics increase the risk of respiratory depression, and in patients with severe pulmonary disease where it is desirable to minimize the use of narcotics.

\section{Acknowledgements}

The authors would like to thank Dr. Tom Phillips and Dr. Wayne Grainger as well as the nursing staff on the orthopaedic ward for their cooperation with the study; we also thank Mrs. Valerie Rapson for preparing the manuscript.

\section{References}

1 Spetzler $B$, Anderson $L$. Patient-controlled analgesia in the total joint arthroplasty patient. Clin Orthop 1987; 215: 122-5.

2 Editorial. Patient-controlled analgesia. Lancet 1980; 1: 289-90.

3 Maunuksela EL, Olkkola KT, Korpela $R$. Does prophylac- tic intravenous infusion of indomethacin improve the management of postoperative pain in children? Can J Anaesth 1988; 35: 123-7.

4 Yrjola H, Silvennoinen T, Vilppula E, Ahistrom-Bengs $E$. Intravenous indomethacin for postoperative pain. A double-blind study of ankle surgery. Acta Orthop Scand 1988; 59: 43-5.

5 Reasbeck PG, Rice ML, Reasbeck JC. Double-blind controlled trial of indomethacin as an adjunct to narcotic analgesia after major abdominal surgery. Lancet 1982; 2 : $115-8$

6 Thind $P$, Sigsgaard $T$. The analgesic effect of indometha$\mathrm{cin}$ in the early postoperative period following abdominal surgery. Acta Chir Scand 1988; 154: 9-12.

7 Beaver $W$. Impact of non-narcotic oral analgesics on pain management. Am J Med 1988; 84 (Suppl 5A): 3-15.

8 Keenan DJM, Cave K, Langdon L, Lea RE. Comparative trial of rectal indomethacin and cryoanalgesia for control of carly post-thoracotomy pain. BMJ 1983; 287: 1335-7.

9 Boardman PL, Hart FD. Side-effects of indomethacin. Ann Rheum Dis 1967; 26: 127-32.

10 Keenan DJM, Cave K, Langdon L, Lea RE. Rectal indomethacin for control of postoperative pain. BMJ 1984; 288: 240.

11 Rane A, Oelz O, Frolich JC et al. Relation between plasma concentration of indomethacin and its effect on prostaglandin synthesis and platelet aggregation in man. Clin Pharmacol Ther 1978; 23: 658-68.

12 Mattila MAK, Ahlstrom-Bengs E, Penttila J, Salmela $J$. The effect of i.v. indomethacin on bleeding time. Acta Anaesthesiol Scand 1983; 27: (Suppl 78), 72.

13 Taivainen $T$, Hiller $A$, Rosenberg $P H$, Neuvonen $P$. The effect of continuous intravenous indomethacin infusion on blecding time and postoperative pain in patients undergoing emergency surgery of the lower extremitics. Acta Anacsthesiol Scand 1989; 33: 58-60.

14 Maunuksela EL, Olkkola KT, Korpela $R$. Intravenous indomethacin as postoperative analgesia in children: acute effects on blood pressure, heart rate, body temperature and bleeding. Ann Clin Res 1987; 19: 359-63.

15 Mattila MAK, Ahlstrom-Bengs E, Pekkola P. Intravenous indomethacin or oxycodone in prevention of postoperative pain. BMJ 1983; 287: 1026.

16 Compendium of Pharmaceuticals and Specialtics 1987; 205.

17 Vesell ES, Passananti GT, Johnson AO. Failure of indomethacin and warfarin to interact in normal human volunteers. J Clin Pharmacol 1975; 15: 486-95.

18 Holt LPJ, Hawkins CF. Indomethacin: studics of absorption and of the use of indomethacin suppositorics. BMJ $1965 ; 1: 1354-7$. 